\title{
HISTONE ADDUCTION WITH NICOTINE: A BIO-AMS STUDY
}

\author{
X. H. WU, H. F. WANG, Y. F. LIU \\ Department of Technical Physics, Peking University, Beijing 100871, China \\ $X . Y . L U, J . J . W A N G$ and $K . L I$ \\ Institute of Heavy Ion Physics, Peking University, Beijing 100871, China
}

\begin{abstract}
Based on the study of DNA adduction with nicotine, we have measured the mouse hepatic histone adduction with ${ }^{14} \mathrm{C}$-labeled nicotine in vivo by bio-accelerator mass spectrometry (bio-AMS). In the exposure of mice to nicotine, the dose range administered was from $0.2 \mu \mathrm{g}$ to $6.0 \mu \mathrm{g} \mathrm{kg} \mathrm{b.w.-1,} \mathrm{which} \mathrm{was} \mathrm{equivalent} \mathrm{to} \mathrm{a} \mathrm{very} \mathrm{low} \mathrm{level} \mathrm{of} \mathrm{human} \mathrm{exposure}$ to cigarette smoke. The adducts of either histone 1 (H1) or histone 3 (H3) with nicotine in mouse liver increased markedly with increasing nicotine dose. Our results have demonstrated that in the study of protein adduction with toxic xenobiotics as a biomarker, the AMS method achieves the highest sensitivity, $4.6 \times 10^{-17}$ mol ( 46 amol) adducts per mg H1 protein, compared to all the other methods used previously.
\end{abstract}

\section{INTRODUCTION}

In recent years, biomarkers have been employed as a sensitive means to indicate the early steps of chemical mutagenesis and carcinogenesis, particularly in a low environmental exposure of humans to toxic chemicals (Ehrenberg and Toernqvist 1992; Beland and Poirier 1993). Accelerator mass spectrometry (AMS) (Weisman 1996) may provide more sensitive measurement of biomarkers than other methods, such as fluorescence spectrometry, radioimmunoassy, ${ }^{32} \mathrm{P}$-postlabling, GC-MS, etc. Pioneering research was first carried out in 1989 by a bio-AMS group at Lawrence Livermore National Laboratory (LLNL) (Felton et al. 1990; Turteltaub et al. 1990). The quantification of the DNA adduction with a ${ }^{14} \mathrm{C}$-labeled carcinogen MeIQx was done by AMS with a detection limit of 1 adduct per $10^{12}$ nucleotides.

In 1996 we presented an AMS study on the measurement of mouse hepatic DNA adduction with tobacco-specific nicotine and its derivative nitrosamine NNK ( $\mathrm{Li}$ et al. 1996). We found a definite correlation between DNA adduct and dose level of nicotine and NNK. These results enable us to speculate that nicotine is a potential carcinogen per se. In this paper, we extend our research of DNA adduction with nicotine to histone protein adduction. Our purpose is to disclose further the damages of tobacco-specific nicotine to humans, other than the well-known addiction factor of smoking, and lung-related illnesses. Moreover, this work demonstrates the feasibility of using histone-nicotine adduct as a biomarker or molecular dosimeter to monitor nicotine-induced carcinogenesis.

Nicotine, 3-(1-methyl-2-pyrrolidinyl)-pyridine, is a major alkaloid in tobacco products, typically comprising $1-2 \%$ weight of tobacco. The pharmacological effect of nicotine is a dominant factor for tobacco addiction. Also, it has proven that nicotine can convert to several nitrosamine derivatives, which are well-known strong carcinogens (Hoffmann and Hecht 1985).

Histones are a class of small positively charged DNA-binding protein found in chromatin of the eukaryotic cell nucleus. In chromatin, a uniquely organized octmer of histones, (H2a, H2b, H3, H4) makes up the core of nucleosome, around which DNA wraps and anchors in the place beside histone H1 (Arents and Moudiranakis 1993; Luger et al. 1997). Histone H1 extracted from calf thymus is composed of 212 amino-acid residues, with lysine/arginine 15.0 and M.W. 21,500; histone H3 135 amino-acid residues, lysine/arginine 0.8 and M.W. 15,300. The conservation of amino-acid composition of histones keeps well across biological species. The gene-regulatory functions of histones have 
been firmly discovered (Grunstein 1992; Wolffe 1992). Thus, histones play a key role in the replication, transcription and repair of DNA.

\section{METHODS}

${ }^{14} \mathrm{C}$-labeled nicotine [pyrrolidine-2-14 $\mathrm{C}$ ] (Fig. 1) was purchased from NEN-Dupont with a very high specific activity of $1.9 \mathrm{GBq} \mathrm{mmol}^{-1}$, equivalent to ${ }^{14} \mathrm{C}$ in $82.14 \%$ of the molecules. ${ }^{14} \mathrm{C}$-nicotine was given to mice (Kunming, 25-30 g b.w.) by tail vein injection. Doses of nicotine were 0.2 to $0.6 \mu \mathrm{g}(\mathrm{kg}$ b.w. $)^{-1}$. Every dose was given to 24 mice, which were divided into 3 groups as 3 parallel samples. Mice were sacrificed at $18 \mathrm{~h}$ post administration. Preparation of hepatic DNA was done following Gupta (1984) and our previous paper (Li et al. 1996). DNA purity was assayed by UV spectrometry.<smiles>CN1CCCC1c1cccnc1</smiles>

Fig. 1. Molecular structure of nicotine. The position of ${ }^{14} \mathrm{C}$ is symbolized with an asterisk.

Preparation of H1 hepatic histone was according to Linder, Helliger and Puschendorf (1990); the extraction of H3 hepatic histone followed Johns (1971) and Linder and Helliger (1990) with some modifications. $\mathrm{HClO}_{4}$-insoluble material from the preparation of $\mathrm{H} 1$ hepatic histone was extracted with 3 vol. of ethanol / $1.25 \mathrm{M} \mathrm{HCl}(4: 1, \mathrm{v} / \mathrm{v})$ for $2 \mathrm{~h}$ in an ice-bath with rocking-mixer. The insoluble material was removed by centrifugation at $8000 \mathrm{~g}$ for $20 \mathrm{~min}$ and soluble proteins were dialyzed at a $10,000 \mathrm{M}$.W. cutoff in ethanol for $22 \mathrm{~h}$ at $2^{\circ} \mathrm{C}$. Ethanol was renewed three times. H3 histone was centrifuged down at $12,000 \mathrm{~g}$ for $20 \mathrm{~min}$, washed once with ethanol and twice with pure acetone, dissolved in $1 \mathrm{mM} 2$-mercaptoethanol, freeze-dried and then stored at $-20^{\circ} \mathrm{C}$. Histones $\mathrm{H} 1$ and $\mathrm{H} 3$ were assayed by these methods: 1. Protein content analysis by Folin-phenol method (a purity of 99-100\% was maintained); 2. SDS-Polyacrylamide gel electrophoresis assay; 3 . amino-acid composition analysis; 4. M. W. determination. Histones were definitely identified.

The conversion of DNA adducts to graphite samples was made after Vogel's protocol (Vogel 1992). It was difficult to convert histone adducts to graphite under the same condition used for DNA adducts. In the conversion of histone adducts, we increased the ignition temperature to $900^{\circ} \mathrm{C}$. The ${ }^{14} \mathrm{C}$ measurements followed a protocol developed for the $2 \times 6$ MV EN Tandem AMS facility at the Institute of Heavy Ion Physics, Peking University (Chen et al. 1990). Our AMS allows measurement of the isotope ratio ${ }^{14} \mathrm{C} /{ }^{12} \mathrm{C}$ with a sensitivity of $7 \times 10^{-15}$ and an instrument precision of $1-4 \%$. The isotope ratio was converted to the number of adducts based on some fundamental data $(1 \mathrm{pMC}=$ $5.9 \times 10^{10}{ }^{14} \mathrm{C} \mathrm{g}^{-1} \mathrm{C} ; 1 \mathrm{~mol} \mathrm{H} 1=212$ amino-acid residues; $1 \mathrm{~mol} \mathrm{H} 3=135$ amino-acid residues; carbon content in histones $=50.0 \%$ ). A graphite sample prepared from Chinese glucose by our sample preparation system was the internal standard.

\section{RESULTS AND DISCUSSION}

The level of ${ }^{14} \mathrm{C}$ of histones and DNA from control mice ranged from 1.24 to $1.30 \mathrm{pMC}$, indicating that the processes of sample preparation and graphite conversion were carried out without excessive ${ }^{14} \mathrm{C}$ contamination. Each datum of all the samples was calculated from a mean value of 5-7 runs of AMS measurements. 


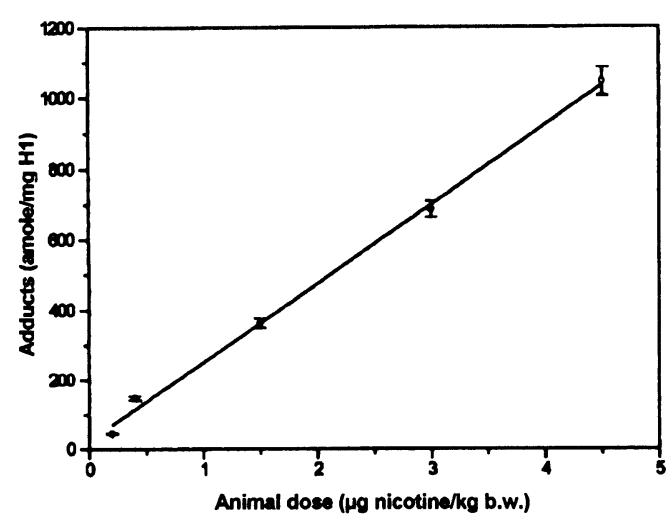

Fig. 2. Influence of nicotine exposure dose on histone $\mathrm{H} 1$ adduct level. Regression results: $\mathrm{Y}=26.70+224.3 \mathrm{X}, \mathrm{r}=$ 0.999 .

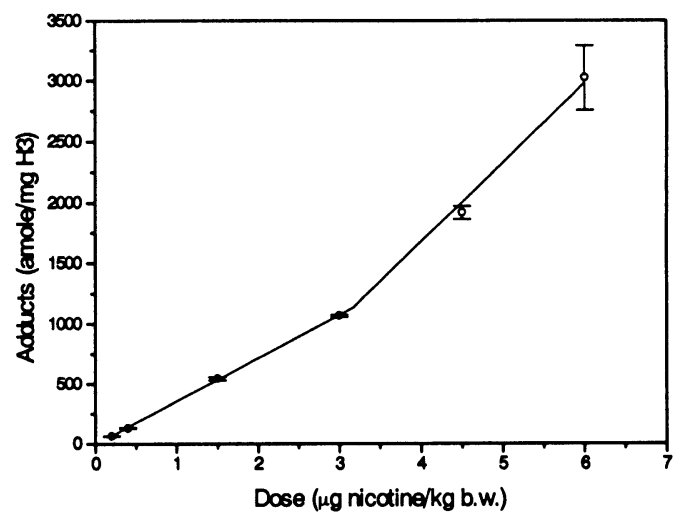

Fig. 3. Influence of nicotine exposure dose on histone $\mathrm{H3}$ adduct level. Regression results: $Y=-6.60+360.33 X, r=$ 0.999 (left); $Y=-930.11+652.12 X, r=0.997$ (right).

Figure 2 shows the influence of nicotine exposure dose on nucleoprotein $\mathrm{H} 1$ adduct level. The number of $\mathrm{H} 1$ adducts increases evidently with increasing exposure dose of nicotine in a linear relationship. It is clear that a nicotine metabolite combines with $\mathrm{H} 1$ in the mouse liver, even at doses as low as $0.2 \mu \mathrm{g} \mathrm{kg} \mathrm{b.w.-1}$.

In Figure 3, nicotine exposure dose also has marked influence on nucleoprotein histone $\mathrm{H} 3$ adduct level; the number of $\mathrm{H} 3$ adducts increases with increasing doses of nicotine, however, in an inflective linear fashion with an inflection point at an intermediate dose level, $3 \mu \mathrm{g} \mathrm{kg} \mathrm{b.w.-}{ }^{-1}$. The dimer of $\mathrm{H} 3$ combines closely with DNA in the nucleosome. In $\mathrm{H} 3$ molecule, the most reactive amino-acid residue cysteine and the considerably reactive residues lysine and methionine hide deeply in the inner structure of the nucleosome (Stacks et al. 1990). Therefore, we may speculate that exceeding the dose level at the inflection point, the outer structure of the nucleosome is loosened by the reaction of a sufficient amount of nicotine, and thus the reactive amino-acid residues emerge from the interior and form more adducts with nicotine.

The main means employed by the tobacco industry to reduce the harm of cigarettes to human health is decreasing the amount of coal tar and nicotine in the cigarette. The amount of nicotine in a cigarette is approximately reduced to $0.8 \mathrm{mg}$ nicotine per cigarette (Hoffman et al. 1994). A filter tip can further reduce the nicotine intake by the body. If the amount of nicotine in one filtered cigarette is 1 $\mathrm{mg}$, a smoker takes in $45 \mu \mathrm{g}$ nicotine through mainstream smoking (direct inhalation) (Adams, O'Mara-Adams and Hoffmann 1987). For a person with $70 \mathrm{~kg}$ body weight, the relationship between the dose of nicotine in the mainstream and the number of filtered cigarettes smoked is shown in Table 1.

TABLE 1. Relation Between Dose of Nicotine and Number of Cigarettes Smoked

\begin{tabular}{ccc}
\hline $\begin{array}{c}\text { Dose of nicotine } \\
\left(\mu \mathrm{g} \mathrm{kg} \mathrm{b.w.} .^{-1} \text { of mouse) }\right.\end{array}$ & $\begin{array}{c}\text { Nicotine intake in the } \\
\text { mainstream, per person }(\mu \mathrm{g})\end{array}$ & $\begin{array}{c}\text { Number of } \\
\text { cigarettes smoked }\end{array}$ \\
\hline 0.2 & 14 & 0.3 \\
0.4 & 28 & 0.6 \\
1.5 & 105 & 2.3 \\
2.0 & 140 & 4.7 \\
4.5 & 315 & 7.0 \\
6.0 & 420 & 9.3 \\
\hline
\end{tabular}


The AMS measurements (Figs. 2-4) show that even at such low doses of nicotine, both DNA and histone adduction exist. This indicates potential damage from nicotine even to casual cigarette smokers. Furthermore, our finding on the definite harm of nicotine to nucleoprotein histones supports our previous point that nicotine is a potential carcinogen per se.

Figure 4 demonstrates that both $\mathrm{H} 1$ and DNA adducts have similar linear relationships with the nicotine dose. It indicates that the histone $\mathrm{H} 1$ adducts are likely to be highly correlated with DNA adducts. Therefore, $\mathrm{H} 1$ adducts can be a good biomarker in the dosimetry of toxicants instead of DNA adducts. Unlike blood proteins, which provide information on systemic exposure, histones provide target tissue-specific data as does DNA. Moreover, histones have an intrinsic advantage over DNA as a biomaker of molecular dosimeters since histones have relatively long lifetimes and are not subject to repair as DNA is. The average half-life has been shown on murine liver and brain to be 117 and 223 days, respectively (Commerford et al. 1982). A molecular dosimeter with a long lifetime is desirable to investigate carcinogen exposures over longer times.

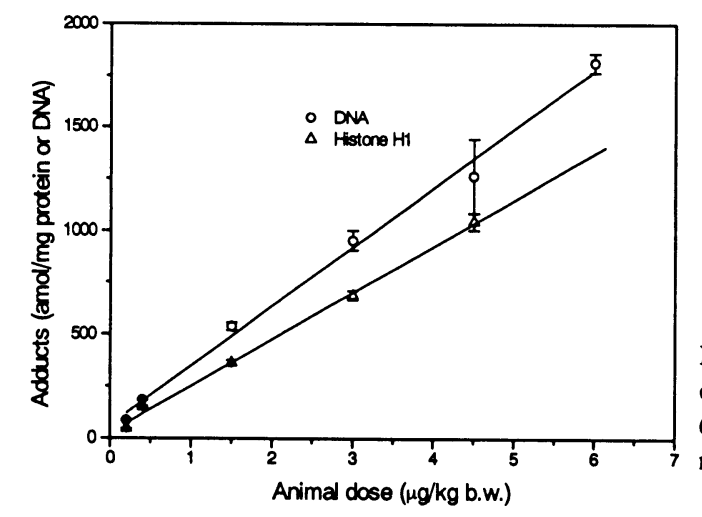

Fig. 4. Comparison of influences of nicotine exposure dose on $\mathrm{H} 1$ and DNA adduct levels. Regression results: $\mathrm{Y}=$ $63.71+285.54 \mathrm{X}, \mathrm{r}=0.997(\mathrm{DNA}) ; \mathrm{Y}=26.70+224.36 \mathrm{X}$, $\mathrm{r}=0.999$ (histone $\mathrm{H} 1$ ).

The result of the smallest nicotine and $\mathrm{H} 1$ adduction, $4.6 \times 10^{-17} \mathrm{~mol}$ (46 amol) adducts per mg H1 protein, shows that our AMS measurement gives the highest sensitivity in the detection of protein adducts. The most sensitive analytical method reported previously was gas chromatography-mass spectrometry (GC-MS) combined with ion-exchange chromatography in the research of hemoglobin adducts (Farmer 1994). The detection limit of that method was 0.05 pmol adducts per $\mathrm{g}$ hemoglobin $(50 \mathrm{amol} \mathrm{mg}-1$ ), but it was only on the basis of the measurement of cysteine adduct without considering the adducts formed with other many amino-acid residues in hemoglobin.

\section{CONCLUSION}

We measured mouse heptic histone adduction as well as DNA adduction with ${ }^{14} \mathrm{C}$-labeled nicotine in vivo by AMS. The administered dose range was equivalent to a very low level of human exposure to cigarette smoking.

The measurement results show that the number of both $\mathrm{H} 1$ and $\mathrm{H} 3$ adducts, as well as DNA adducts, increase with increasing exposure dose of nicotine in a linear relationship, indicating that nicotine damages DNA and its closely related important nucleoprotein histones through its molecular bindings. This supports our previous point that nicotine may be carcinogenic.

Our AMS measurement gives the highest sensitivity, 46 amol adducts per mg protein, in the detection of protein adducts with toxic xenobiotics as a biomarker, of any method employed so far. 


\section{ACKNOWLEDGMENTS}

We thank the National Natural Science Foundation of China for financial support (Project 19392100). We are also thankful to Profs. C. E. Chen, Z. Y. Guo and X. Y. Wang for their support and assistance.

\section{REFERENCES}

Adams, J. D., O'Mara-Adams, K. J. and Hoffmann, D. 1987 Toxic and carcinogenic agents in undiluted mainstream smoke and sidestream smoke of different types of cigarettes. Carcinogenesis 8: 729-731.

Arents, G. and Moudrianakis, E. N. 1993 Topography of the histone octomer surface: Repeating structural motifs utilized in the docking of nucleosomal DNA. Proceedings of the National Academy of Sciences 90: 10489-10493.

Beland, F. A. and Poirier, M. C. 1993 Significance of DNA adduct studies in animal models for cancer molecular dosimetry and risk assessment. Environmental Health Perspectives 99: 5-10.

Chen, C. E., Guo, Z. Y., Yan, S. Q., Zhang, Z. F., Gong, L. H., Li, R. X. and Yu, J. K. 1990 Status of the tandem accelerator mass spectrometry facility at Peking University. Nuclear Instruments and Methods in Physics Research B52: 306-309.

Commerford, S. L., Carsten, A. L. and Croakite, E. P. 1982 Histone turnover within nonproliferating cells. Proceedings of the National Academy of Sciences 79: 1163-1165.

Ehrenberg, L. and Toernqvist, M. 1992 Use of biomarkers in epidemicology: Quantitative aspects. Toxicology Letter 64-65: 485-492.

Farmer, P. B. 1994 Carcinogen adducts: Use in diagnosis and risk assessment. Clinical Chemistry 40(7): 14381443.

Felton, J. S., Turteltaub, K. W., Vogel, J. S., Balhorn, R., Gledhill, B. L., Southon, J. R., Caffee, M. W., Finkel, R. C., Nelson, D. E., Proctor, I. D. and Davis, J. C. 1990 Accelerator mass spectrometry in the biomedical and environmental dosimetry. Nuclear Instruments and Methods in Physics Research B52: 517-523.

Grunstein, M. 1992 Histones as regulators of genes. Scientific American 267(4): 40-47.

Gupta, R. C. 1984 Nonrandom binding of the carcinogen $\mathrm{N}$-hydroxy-2-acetylaminofluorene to repetitive sequences of rat liver DNA in vivo. Proceedings of the National Academy of Sciences 81: 6943-6947.

Hoffmann, D., Brunnemann, K. D., Prokopczyk, B. and Djordjevic, M. D. 1994 Tobacco-specific N-nitrosamines: Chemistry, carcinogenicity, and relevance to humans. Journal of Toxicology \& Environmental

Health 41: 1-52.

Johns, E. W. 1971 The preparation and characterization of histones. In Phillips, D. M. P., ed., Histones and Nucleohistones. London and New York, Plenum Press: 10-15.

Li, X. S., Wang, H. F., Shi, J. Y., Wang, X. Y., Liu, Y. F., Li, K., Lu, X. Y., Wang, J. J., Liu, K. X. and Guo, Z. Y. 1996 Genotoxicity study on nicotine and nicotinederived nitrosamine by accelerator mass spectrometry. Radiocarbon 38(2): 347-353.

Linder, H. and Helliger, W. 1990 Effects of eluent composition, ion-pair reagent and temperature on the separation of histiones by HPLC. Chromatography 30(9/ 10): 518-522.

Linder, H., Helliger, W. and Puschendorf, B. 1990 Separation of rat tissue histone $\mathrm{H} 1$ subtypes by reversephase HPLC. Biochemical Journal 269: 359-363.

Luger, K., Maeder, A. W., Richmond, R. K., Sargent, D. F. and Richmond, T. J. 1997 Crystal structure of the nucleosome core particle at 2.8 a resolution. Nature 389: 251-160.

Stacks, P. C., Mazrimas, J. A., Corzett, M. and Balhorn, R. 1990 Reactivity and adduct formation of a polyaromatic hydrocarbon, 7-bromomethylbenz(a)anthracene, with chromatin histone proteins. Journal of Chromatography 528: 25-34.

Turteltaub, K. W., Felton, J. S., Gledhill, B. L., Vogel, J. S., Southon, J. R., Caffee, M. W., Finkel, R. C., Nelson, D. E., Proctor, I. D. and Davis, J. C. 1990 Accelerator mass spectrometry in biomedical dosimetry: Relationship between low-level exposure and covalent binding of heterocyclic amine carcinogens to DNA. Proceedings of the National Academy of Sciences 87: 5288-5292.

Vogel, J. S. 1992 rapid production of graphite without contamination for biomedical AMS. In Proceedigs of the 14 th International ${ }^{14} \mathrm{C}$ Conference. Radiocarbon 34(3): 344-350.

Weisman, J. 1996 AMS adds realism to chemical risk assessment. Science 271: 286-287.

Wolffe, A. P. 1992 New insights into chromatin function in transcriptional control. The Federation of American Society for Experimental Biology Journal 6: 33543361 . 